\title{
MENINGKATKAN PEMAHAMAN SISWA TENTANG SIFAT-SIFAT PERKALIAN BILANGAN CACAH MENGGUNAKAN TALI RAFIA DAN STYROFOAM PERSEGI
}

\author{
Beni Asyhar \\ Program Studi Tadris Matematika \\ Sekolah Tinggi Agama Islam Negeri (STAIN) Tulungagung \\ e-mail: asyhar_beni@yahoo.com
}

\begin{abstract}
ABSTRAK
Penelitian ini bertujuan untuk meningkatkan pemahaman siswa tentang sifat-sifat perkalian bilangan cacah menggunakan tali rafia dan styrofoam persegi di SDN Gadang 2 Kota Malang. Rancangan penelitian yang digunakan adalah penelitian tindakan kelas (PTK). Penelitian dilaksanakan pada siswa kelas II. Subjek wawancara 5 siswa yang terdiri dari 1 siswa berkemampuan tinggi, 3 siswa berkemampuan sedang, dan 1 siswa berkemampuan rendah. Pemilihan subjek wawancara berdasarkan hasil tes awal dan pertimbangan bahwa siswa-siswa tersebut mudah diajak komunikasi. Hasil penelitian ini adalah: 1) penggunaan tali rafia dan styrofoam persegi ternyata dapat meningkatkan pemahaman siswa yang terbagi dalam tiga tahap pembelajaran, yaitu: (i) tahap awal meliputi menyampaikan tujuan pembelajaran, pemberian motivasi tentang pentingnya perkalian bilangan cacah, memeriksa pengetahuan prasyarat, dan membagikan alat peraga dan LKS, (ii) tahap inti meliputi pelaksanaan diskusi kelompok dan presentasi hasil diskusi, dan (iii) tahap akhir meliputi membuat kesimpulan dan evaluasi, 2) pembelajaran menggunakan tali rafia dan styrofoam persegi dapat meningkatkan pemahaman siswa tentang konsep perkalian dan sifat-sifat perkalian bilangan cacah, dan 3) respon siswa terhadap pembelajaran dengan menggunakan tali rafia dan styrofoam persegi pada materi perkalian dan sifat-sifat perkalian bilangan cacah positif.
\end{abstract}

Kata kunci: Rafia, Styrofoam Persegi, Sifat-sifat Perkalian Bilangan Cacah

\begin{abstract}
This study aimed to improve students' understanding on the properties of whole numbers multiplication using raffia and square styrofoam in SDN of Gadang 2 Malang City. This study employed a classroom action research design (CAR). The subjects of this study were students in grade two. The interviewees consisted of five students, 1 high level student, 3 moderate level students, and 1 low level student. The subjects were chosen based on the result of preliminary test and a consideration that the researcher could communicate with them easily. The results of the study showed that: 1) learning by using raffia and square styrofoam could improve students' understanding on multiplication concept and properties of whole numbers multiplication with three stages of learning, namely: (i) the first stage involved informing the learning objectives, motivating the students about the importance of whole numbers multiplication, checking the background knowledge, and distributing visual learning aids and worksheet, (ii) the main stage included discussing and presenting the result of group discussion, and (iii) the last stage involved drawing conclusion and evaluation, and 2) the students had positive responses toward the learning process by using raffia and square styrofoam on the multiplication concept and properties of whole numbers multiplication.
\end{abstract}

Keywords: Raffia, Square Styrofoam, The Properties of Whole Numbers Multiplication

\section{PENDAHULUAN}

Matematika merupakan ilmu yang banyak diperlukan dalam kehidupan sehari-hari (Sujono, 1988:13). Selain diperlukan dalam kehidupan sehari-hari, matematika diperlukan untuk membentuk pola pikir seseorang yang sistematis, logis, dan cermat (Karso, 1998:1.4). Mata pelajaran matematika perlu diberikan kepada semua peserta didik di sekolah untuk membekali peserta didik dengan kemampuan berpikir logis, analitis, sistematis, kritis, dan kreatif, serta kemampuan bekerjasama (Depdiknas, 2006:416).

Menurut Peraturan Menteri Pendidikan Nasional Republik Indonesia Nomor 22 Tahun 2006 Tentang Standar Isi untuk Satuan Pendidikan Dasar dan Menengah (Depdiknas, 2006:416) bahwa matematika merupakan salah satu mata pelajaran wajib yang diberikan kepada siswa sejak Sekolah Dasar (SD). Salah satu tujuan 
mata pelajaran matematika diberikan kepada peserta didik di sekolah adalah agar peserta didik memiliki kemampuan memahami konsep matematika, menjelaskan keterkaitan antar konsep dan mengaplikasikan konsep atau algoritma, secara luwes, akurat, efisien, dan tepat, dalam pemecahan masalah (Depdiknas, 2006:417).

Menurut Peraturan Menteri Pendidikan Nasional Republik Indonesia Nomor 22 Tahun 2006 Tentang Standar Isi untuk Satuan Pendidikan Dasar dan Menengah, salah satu kompetensi dasar siswa kelas II SD adalah melakukan perkalian bilangan yang hasilnya bilangan dua angka (Depdiknas, 2006:421). Konsep perkalian mulai diberikan kepada siswa SD kelas II pada semester II. Konsep perkalian yang diberikan masih konsep perkalian bilangan cacah dan masih terbatas pada hasil perkalian bilangan dua angka. Misalnya perkalian antara bilangan 4 dengan 5 yang menghasilkan bilangan dua angka, yaitu bilangan 20 atau jika disimbolkan menjadi $4 \times 5=20$ (dibaca "empat kali lima sama dengan dua puluh").

Kenyataan di lapangan menunjukkan bahwa siswa SD belum paham terhadap konsep perkalian. Sesuai hasil dialog dengan guru yang sudah berpengalaman mengajar di kelas rendah terutama di kelas II SD pada hari Jum'at, tanggal 16 Desember 2011 di Sekolah Dasar Negeri (SDN) Gadang 2 Kota Malang, setelah siswa memperoleh penjelasan materi tentang perkalian dari guru dan dilakukan tes, mereka tidak dapat menjelaskan prosedur menghitung perkalian. Siswa hanya sekedar dapat menyelesaikan soal tentang perkalian, tetapi mereka tidak dapat menjelaskan hasil perkalian bilangan tersebut. Misalnya $3 \times 5=15$ dan $5 \times 3=15$. Mereka menganggap bahwa $3 \times 5$ dan $5 \times 3$ memiliki arti yang sama, padahal keduanya memiliki arti yang berbeda meskipun memiliki hasil perkalian yang sama. Selain tidak dapat menjelaskan prosedur menghitung perkalian, dari hasil wawancara peneliti dengan siswa kelas II SDN Gadang 2 mayoritas siswa hanya belajar dengan menghafalkan definisi, menghafalkan rumus, mengerjakan contoh soal dan latihan-latihan soal yang ada di buku. Siswa tidak berusaha membangun konsep perkalian berdasarkan pembentukan pengetahuan siswa sendiri, siswa hanya sekedar menghafal konsep perkalian. Padahal siswa SD berumur antara 7-12 tahun, yang menurut Piaget (Orton, 2004:52) perkembangan kognitifnya termasuk dalam tahap operasional konkret. Hal ini berarti bahwa siswa SD masih sangat tergantung pada bendabenda konkret atau hal-hal nyata untuk dapat memahami sesuatu.
Perkembangan kognitif siswa SD bergerak dari sesuatu yang konkret, semikonkret, dan abstrak. Hal ini sesuai dengan pendapat Bruner (dalam Orton, 2004:178) bahwa perkembangan kognitif siswa SD bergerak dari tahap enactive, iconic, dan symbolic. Tahap enactive merupakan tahap belajar siswa dengan memanipulasi bendabenda konkret. Tahap iconic merupakan tahap belajar siswa dengan menggunakan gambar (semikonkret). Tahap symbolic merupakan tahap belajar siswa melalui manipulasi lambang atau simbol (abstrak). Contoh perkembangan kognitif siswa SD dalam matematika menurut teori belajar Bruner adalah sebagai berikut: 1) tahap enactive. Penyajian yang dilakukan pada tahap ini adalah melalui tindakan anak secara langsung memanipulasi (mengutak-atik) objek. Perwakilan siswa diberikan tali rafia dengan ukuran tertentu dan diminta untuk memegang dan meletakkan tali rafia tersebut di atas lantai ruang kelas kemudian siswa yang lain diminta untuk menghitung banyaknya ubin persegi yang dibatasi oleh tali rafia tersebut. Siswa menghitung menurut kemampuan dari masingmasing siswa. 2) tahap iconic. Penyajian dilakukan berdasarkan pada pengetahuan siswa melalui serangkaian gambar-gambar atau grafik yang sudah dialami sendiri oleh anak, yaitu gambaran dari objek-objek yang dimanipulasi pada tahap enactive. Pada tahap ini, guru meminta kepada siswa untuk menggambarkan ulang susunan ubin lantai yang dibatasi tali rafia di buku, kemudian siswa diminta untuk menghitung banyaknya ubin yang dibatasi tali rafia tersebut dan dilanjutkan dengan memberi nama susunan ubin persegi yang dibatasi tali rafia tersebut. 3) tahap symbolic. Penyajian dilakukan dengan simbol-simbol atau lambanglambang. Guru menuliskan simbol perkalian dari suatu susunan ubin lantai yang dibatasi tali rafia, kemudian siswa diminta untuk menghitung hasilnya.

Tahap enactive merupakan tahap yang sangat penting untuk siswa SD karena perkembangan kognitif siswa SD masih berada dalam tahap operasional konkret (Orton, 2004:52). Siswa SD dalam memahami suatu konsep masih harus diberikan suatu kegiatan yang berhubungan dengan benda nyata atau kejadian nyata yang dapat diterima oleh akal mereka. Menurut Soedjadi (2000:41), tahap ini adalah untuk mengurangi sifat keabstrakan objek matematika agar menjadi konkret dan lebih mudah dipahami oleh siswa SD yang masih berada dalam tahap operasional konkret. Untuk mengenalkan suatu bilangan kepada siswa SD, misalnya fakta "7" tidak langsung dikenalkan simbol tujuh, akan tetapi dimulai dengan mengenalkan menggunakan sesuatu yang berupa 
alat, bahan, atau benda konkret, misalnya ubin lantai yang banyaknya tujuh. Setelah siswa menangkap makna kata tujuh, kemudian dikenalkan simbol tujuh yang lebih abstrak.

Penggunaan alat, bahan, atau benda konkret yang digunakan oleh guru untuk mengenalkan suatu konsep matematika disebut perantara komunikasi kegiatan pembelajaran. Sesuatu yang dapat digunakan sebagai perantara komunikasi dalam kegiatan pembelajaran disebut media pembelajaran (Setyosari dan Sihkabuden, 2005:18). Menurut Daryanto (2011:4), media pembelajaran merupakan sarana yang menjadi perantara dalam proses belajar mengajar. Pada tahap ini, penggunaan media pembelajaran matematika yang dimaksud adalah penggunaan bahan atau benda konkret yang bentuknya dapat diubah, banyaknya dapat ditambah atau dikurangi yang dapat menjelaskan suatu konsep matematika yang sifatnya abstrak agar siswa SD lebih menghayati matematika secara nyata berdasarkan fakta yang jelas dan dapat dilihatnya. Sehingga siswa SD lebih mudah memahami topik yang disajikan.

Salah satu fungsi media pembelajaran adalah untuk mengubah objek matematika yang pada awalnya bersifat abstrak menjadi lebih konkret atau yang pada awalnya teoritis menjadi praktis (Setyosari dan Sihkabuden, 2005:19). Menurut Ruseffendi (1988:2), semua benda yang digunakan sebagai alat bantu untuk menerangkan atau mewujudkan suatu konsep matematika atau mengubah objek matematika yang bersifat abstrak menjadi konkret disebut alat peraga matematika. Alat peraga matematika dapat berupa apa saja yang ada dalam kehidupan sehari-hari yang berwujud, dapat diraba, dipegang, dipindahkan, dipasangkan, dan dapat dimanfaatkan untuk membantu pemahaman siswa dalam memahami suatu konsep matematika. Ruseffendi (1988:3) menjelaskan bahwa ada beberapa persyaratan yang harus diperhatikan dalam membuat media pembelajaran berupa alat peraga, yaitu: 1) tahan lama (dibuat dari bahan-bahan yang cukup kuat); 2) bentuk dan warnanya menarik; 3) sederhana dan mudah dikelola; 4) ukuran sesuai atau seimbang dengan ukuran fisik dari peserta didik; 5) dapat memperjelas konsep matematika, baik dalam bentuk real, gambar atau diagram dan bukan sebaliknya (mempersulit pemahaman konsep matematika); 6) sesuai dengan konsep matematika; 7) dapat menunjukkan konsep matematika dengan jelas; 8) peragan diharapkan menjadi dasar bagi tumbuhnya konsep berpikir abstrak bagi peserta didik; 9) alat peraga tersebut dapat dimanipulasikan (dapat diraba, dipegang, dipindahkan, dipasangkan, dan sebagainya) agar peserta didik dapat belajar secara aktif baik secara individual maupun kelompok; 10) bila mungkin alat peraga tersebut dapat berfaedah banyak.

Berdasarkan beberapa persyaratan yang dikemukakan oleh Ruseffendi (1988:3), dalam kehidupan sehari-hari banyak dijumpai alat, bahan, atau benda-benda konkret yang dapat digunakan sebagai media pembelajaran untuk mengenalkan suatu konsep matematika, diantaranya tali rafia dan styrofoam. Tali rafia dan styrofoam merupakan suatu benda konkret yang sangat mudah untuk mendapatkannya dalam kehidupan sehari-hari. Tali rafia dapat diperoleh dari toko-toko kecil sekitar lingkungan sekolah atau lingkungan rumah. Sedangkan styrofoam dapat diperoleh dengan mengambil styrofoam bekas pengaman barang-barang elektronik atau dapat diperoleh dari toko alatalat tulis sekitar lingkungan sekolah atau lingkungan rumah. Tali rafia dan styrofoam dapat digunakan untuk membantu siswa SD memahami suatu materi pelajaran, dalam hal ini adalah pokok bahasan tentang konsep sifat-sifat perkalian. Dengan menggunakan tali rafia dan styrofoam, siswa SD dikenalkan secara langsung konsep perkalian dengan menghitung banyaknya susunan ubin lantai yang dibatasi tali rafia atau susunan styrofoam yang sudah dipotong dengan ukuran tertentu. Dengan media pembelajaran matematika yang konkret tersebut, siswa SD diajak belajar matematika yang sifatnya abstrak menjadi lebih konkret dan membangun pengetahuannya sendiri, tidak sekedar menghafal saja.

Berdasarkan uraian di atas, untuk mengajarkan suatu konsep matematika harus disesuaikan dengan tahap perkembangan kognitif siswa. Perkembangan kognitif siswa SD masih berada pada tahap operasional konkret, sehingga untuk mengenalkan suatu konsep matematika kepada siswa SD lebih tepat dimulai dengan mengenalkan menggunakan benda-benda konkret yang ada dalam kehidupan sehari-hari untuk mewujudkan objek matematika yang bersifat abstrak.

Sesuai dengan hasil penelitian Marzuki (2001) yang memfokuskan penelitiannya pada upaya meningkatkan pemahaman konsep perkalian bilangan cacah dengan manipulasi benda-benda konkret kepada siswa kelas II SD menyimpulkan bahwa melalui manipulasi bendabenda konkret dapat meningkatkan pemahaman konsep perkalian bilangan cacah secara optimal.

Benda-benda konkret dalam kehidupan sehari-hari yang dapat digunakan untuk mewujudkan objek matematika yang bersifat 
abstrak diantaranya adalah tali rafia dan styrofoam. Tali rafia dan styrofoam dapat digunakan untuk mengenalkan konsep sifat-sifat perkalian kepada siswa SD yang masih berada pada tahap operasional konkret. Oleh karena itu, penggunaan benda-benda konkret berupa tali rafia dan styrofoam sangat diperlukan karena perkembangan kognitif siswa SD yang masih berada pada tahap operasional konkret. Kemudian untuk mengetahui lebih jauh tentang penggunaan tali rafia dan styrofoam, peneliti melakukan penelitian yang bertujuan untuk meningkatkan pemahaman siswa tentang sifatsifat perkalian bilangan cacah menggunakan tali rafia dan styrofoam persegi di Sekolah Dasar Negeri (SDN) Gadang 2 Kota Malang.

\section{TEORI DASAR}

\section{Pengertian Media Pembelajaran}

Menurut Gerlach dan Ely (1971) dalam Arsyad (2009:3), media adalah manusia, materi, atau kejadian yang membangun kondisi dan membuat siswa mampu memperoleh pengetahuan, keterampilan, atau sikap. Secara khusus, media dalam proses belajar mengajar dapat diartikan sebagai alat-alat grafis, photografis, atau elektronik untuk menangkap, memproses, dan menyusun kembali informasi visual atau verbal. Heinich, et. al. (2002:9-10) mengatakan bahwa: "a medium (plural, media) is a channel of communication. Example include video, television, diagrams, printed materials, computers, and instructors". Jika diterjemahkan secara bebas, media adalah saluran komunikasi termasuk video, televisi, diagram, media cetak, komputer, dan panduan. Menurut Setyosari dan Sihkabuden (2005:16), media adalah suatu alat atau sarana atau perangkat yang berfungsi sebagai perantara atau saluran atau jembatan dalam kegiatan komunikasi (penyampaian dan penerimaan pesan) antara komunikator (penyampai pesan) dan komunikan (penerima pesan). Berikutnya, Asyhar (2011:5) mengatakan bahwa: media memiliki peran yang sangat penting sebagai sarana atau perangkat yang berfungsi sebagai perantara atau saluran dalam suatu proses komunikasi antara komunikator dan komunikan.

Berdasarkan beberapa pengertian tentang media di atas, media adalah suatu alat atau sarana atau perangkat yang digunakan sebagai alat bantu memudahkan pengirim pesan untuk mengirimkan pesan tertentu kepada penerima pesan.

Pembelajaran adalah upaya untuk membelajarkan pebelajar. Membelajarkan berarti suatu usaha untuk menjadikan seseorang menjadi belajar (Setyosari dan Sihkabuden, 2005:17). Dalam upaya pembelajaran terdapat proses komunikasi antara pebelajar (siswa) dengan pembelajar (guru). Proses komunikasi antara siswa dengan guru dapat dikenal sebagai proses pembelajaran. Proses komunikasi antara si pebelajar (siswa) dengan pembelajar (guru) adalah proses penyampaian pesan oleh guru kepada siswa. Proses penyampaian pesan itu perlu adanya suatu sarana atau alat. Heinich, et. al. (2002:6) menambahkan bahwa "learning is the development of new knowledge, skills, or attitudes as an individual interacts with information and environment". Jika diterjemahkan secara bebas, pembelajaran adalah pengembangan pengetahuan baru, keterampilan, atau sikap individu yang berhubungan dengan informasi dan lingkungan. Asyhar (2011:7) menambahkan bahwa pembelajaran adalah segala sesuatu yang dapat membawa informasi dan pengetahuan dalam interaksi yang berlangsung antara guru dengan siswa. Pada saat pembelajaran berlangsung, media pembelajaran berperan sebagai penyampai pesan-pesan pembelajaran.

Berdasarkan beberapa pengertian tentang pembelajaran di atas, pembelajaran adalah upaya untuk menjadikan seseorang menjadi belajar, yang di dalamnya terdapat segala sesuatu yang dapat membawa informasi dan pengetahuan dalam interaksi yang berlangsung antara guru dengan siswa.

Setelah memahami pengertian "media" dan "pembelajaran", dapat disimpulkan bahwa media pembelajaran adalah suatu alat atau sarana apa saja yang dapat digunakan sebagai alat bantu atau perantara komunikasi antara guru dan siswa sehingga terjadi lingkungan belajar yang kondusif dan proses pembelajaran berlangsung secara efisien dan efektif.

Pada penelitian ini, peneliti menggunakan tali rafia dan styrofoam. Dari pengertian media pembelajaran yang telah dipaparkan di atas, tali rafia dan styrofoam dapat dikategorikan sebagai media pembelajaran, yaitu suatu alat bantu yang dapat digunakan sebagai perantara komunikasi antara siswa dan guru. Peneliti menduga bahwa penggunaan tali rafia dan styrofoam dapat meningkatkan hasil belajar siswa dan dapat membantu siswa dalam memahami materi perkalian. Hal ini karena tali rafia dan styrofoam dapat dibentuk menyerupai bentuk aslinya, sehingga dapat memudahkan siswa dalam mempelajari sesuatu yang bersifat abstrak.

Dipilihnya tali rafia dan styrofoam dalam penelitian ini karena bahan-bahan tersebut mudah untuk mendapatkannya dalam kehidupan sehari-hari, sederhana, ukurannya 
seimbang dengan kondisi fisik siswa, dan dapat dimanipulasikan oleh siswa.

\section{Kedudukan Media Pembelajaran}

Dalam proses pembelajaran terjadi suatu komunikasi antara siswa dan guru (Sudjana, 2011:31). Pada proses komunikasi ini terjadi pemindahan pesan dari guru (pengirim pesan) kepada siswa (penerima pesan). Pesan yang dimaksud dalam hal ini adalah isi ajaran dan didikan yang ada di kurikulum suatu sekolah yang dituangkan oleh guru atau sumber lain ke dalam simbol-simbol komunikasi baik simbol verbal maupun visual (Sadiman, dkk., 2011:12). Pada saat guru menuangkan isi ajaran dan didikan ke dalam simbol-simbol verbal maupun visual diperlukan suatu media pembelajaran agar simbol-simbol (pesan-pesan) tersebut dapat terima dengan baik oleh si penerima pesan (siswa). Media pembelajaran menempati posisi yang cukup penting sebagai salah satu komponen sistem pembelajaran karena proses pembelajaran merupakan proses komunikasi dan berlangsung dalam suatu sistem (Djamarah dan Zain, 2010:120). Tanpa media, komunikasi tidak akan terjadi dan proses pembelajaran sebagai proses komunikasi juga tidak akan bisa berlangsung secara optimal. Bahan atau materi yang tidak jelas dapat disampaikan melalui perantara media pembelajaran sebagai alat bantu. Kerumitan bahan atau materi yang akan disampaikan kepada siswa dapat disederhanakan dengan bantuan media pembelajaran. Keabstrakan bahan atau materi yang akan disampaikan dapat dikonkretkan dengan bantuan media pembelajaran.

Media pembelajaran sangat berperan dalam pembelajaran (Smaldino, et al., 2011:14). Media pembelajaran dapat digunakan sebagai pendukung penyajian pengajaran apabila pengajarannya berpusat pada guru. Selain sebagai pendukung penyajian pengajaran, siswa merupakan pengguna utama media pembelajaran apabila pengajaran berpusat pada siswa.

Media pembelajaran dapat berperan sebagai alat bantu. Sebagai alat bantu, media pembelajaran dapat membantu tercapainya tujuan pembelajaran karena dalam proses pembelajaran dengan bantuan media dapat meningkatkan kegiatan belajar siswa dalam waktu yang cukup lama atau dalam artian bahwa dengan adanya bantuan media pembelajaran akan menghasilkan proses dan hasil pembelajaran yang lebih baik (Djamarah dan Zain, 2010:121). Menurut Asyhar (2011:28), media pembelajaran merupakan alat bantu mengajar, termasuk salah satu komponen lingkungan belajar yang dirancang oleh guru. Media pembelajaran merupakan bagian tak terpisahkan dari proses pembelajaran. Penggunaan media pembelajaran yang optimal perlu didasarkan pada kebermaknaan dan nilai tambah yang dapat diberikan kepada siswa melalui suatu pengalaman belajar yang menggunakan media pembelajaran.

Selain media pembelajaran dapat berperan sebagai alat bantu, media pembelajaran juga berperan sebagai sumber belajar (Djamarah dan Zain, 2010:122). Pendidikan di masa lalu, guru dijadikan sebagai satu-satunya sumber belajar bagi siswa. Pada saat itu kegiatan pembelajaran masih berjalan secara tradisional. Perangkat teknologi dan penyebarannya masih sangat terbatas dan belum memasuki dunia pendidikan. Tetapi sekarang ini, teknologi sudah menyebar luas dan sudah menjadi kebutuhan sehari-hari. Oleh karena itu, dengan adanya perkembangan teknologi tersebut disepakati bahwa media tidak hanya terbatas sebagai alat bantu, akan tetapi juga sebagai sumber belajar dalam proses pembelajaran. Sebagai sumber belajar, media pembelajaran berperan sebagai alat bantu auditif, visual, dan audiovisual. Dalam penggunaannya harus disesuaikan dengan rumusan tujuan pembelajaran dan disesuaikan dengan kompetensi guru.

Pada penelitian ini, media pembelajaran yang berupa tali rafia dan styrofoam dapat berperan sebagai alat untuk mencapai tujuan pembelajaran. Penggunaan media pembelajaran yang optimal perlu didasarkan pada kebermaknaan dan nilai tambah yang dapat diberikan kepada siswa melalui suatu pengalaman belajar karena media pembelajaran merupakan salah satu bagian yang tidak terpisahkan dalam proses pembelajaran.

\section{Jenis-jenis Media Pembelajaran}

Jenis-jenis media sangat luas kategorinya seperti yang dikemukakan oleh Smaldino et. al. (2011:7) bahwa media memiliki cakupan yang sangat luas, di antaranya: teks, audio, visuals, video, perekayasa (manipulative), dan orangorang. Berdasarkan pendapat Smaldino, guru dapat dikategorikan sebagai media pembelajaran.

Ada 4 jenis media, yaitu: 1) media visual, 2) media audio, 3) media audio-visual, dan 4) multimedia (Asyhar, 2011:44-46). Tali rafia dan styrofoam termasuk pada kategori media visual, yaitu media realitas yang ada dalam kehidupan sehari-hari. Dengan menggunakan media tali rafia dan styrofoam, siswa dapat mengalami langsung dalam proses pembelajaran. Siswa dapat bersentuhan langsung dengan media tali rafia dan styrofoam yang sudah disiapkan dan dibentuk menyerupai sifat aslinya. 


\section{Pemahaman Konsep Matematika}

Kata paham atau mengerti adalah satu kata yang sangat sering diucapkan dalam proses pembelajaran matematika di dalam kelas. Guru mengkoordinir berbagai kegiatan dan memfasilitasi berbagai proses pembelajaran dengan tujuan siswa memahami apa yang ingin disampaikannya sejalan dengan rencana pembelajaran yang telah dipersiapkan sebelumnya. Pertanyaan "Apakah kalian sudah mengerti?", "Apakah kalian sudah paham?" sering diucapkan oleh guru tanpa adanya rasa bosan. Pertanyaan tersebut digunakan oleh seorang guru dalam rangka untuk memeriksa efektivitas kegiatan proses pembelajaran di dalam kelas.

Banyak ahli dan praktisi pendidikan yang membahas tentang pemahaman konsep matematika. Skemp (1976) membedakan pemahaman ini menjadi dua bagian, yaitu: "instrumental understanding" (pemahaman instrumental) dan "relational understanding" (pemahaman relasional). Pemahaman instrumental mengacu pada aturan-aturan tanpa alasan, yaitu kemampuan menggunakan aturanaturan matematis tanpa menyadari alasan penggunaan aturan tersebut. Namun kemudian pemahaman ini disanggahnya dengan menuliskan kembali pada artikel yang sama bahwa, "Instrumental understanding I would until recently not have regarded as understanding at all". Skemp melihat bahwa pemahaman instrumental bukanlah pemahaman konsep yang sesungguhnya, karena kebanyakan orang yang menyebut diri mereka memiliki pemahaman ini hanya menggunakan aturan tanpa alasan dan memiliki kemampuan untuk menggunakannya karena mereka memang mengingat cara untuk melakukannya. Pemahaman relasional mengacu pada mengetahui apa yang harus dilakukan dan mengapa melakukannya. Pemahaman inilah yang dimaksud Skemp, termasuk pada penelitian ini, sebagai pemahaman sesungguhnya.

Pemahaman adalah suatu aspek dari hidup seseorang; merupakan suatu pernyataan mental; atau merujuk pada kapasitas seseorang untuk bertindak dengan cara yang sesuai dan mengindikasikan pemahaman yang dimilikinya (Porteous, 2008). Pernyataan mental seseorang akan suatu konsep (matematis) sangat dipengaruhi oleh pengetahuannya tentang konsep tersebut. Pengetahuan ini merupakan hasil pengalaman yang didapat secara sengaja maupun tidak sengaja selama kurun waktu kehidupannya. Pengetahuan atau pemahaman ini dimulai dengan benda atau peristiwa nyata yang dialami dan informasi yang diterimanya dalam kehidupan sehari-hari. Pemahaman ini kemudian termodifikasi menjadi pemahaman yang formal dan sengaja dibentuk oleh adanya pendidikan matematika yang diterimanya di sekolah.

Pemahaman seseorang erat kaitannya dengan pengalaman atau informasi yang diterimanya. Pengalaman dan informasi tersebut sebagian besar diperoleh dari proses belajar mengajar di sekolah. Pada dasarnya sebagian besar kegiatan di kelas memang bertujuan untuk membuat siswa mengingat apa yang telah dipelajari. Namun dengan adanya pemahaman, usaha untuk mengingat menjadi berkurang karena pemahaman membentuk suatu kesatuan konsep yang tersimpan dalam otak yang sewaktu-waktu dapat diakses kembali sesuai dengan kebutuhan. Hal ini sejalan dengan pendapat Cockcroft (1986:231) yang menyebutkan bahwa pemahaman konsep matematis merupakan isyarat dari suatu kemampuan untuk mengenali dan memanfaatkan suatu konsep matematis dalam berbagai macam keadaan, mencakup beberapa hal yang tidak dikenal secara umum.

Pemikiran lain mengenai pemahaman disampaikan oleh Haylock dalam Porteous (2008). Ia berpendapat bahwa "...to understand something means to make (cognitive) connections". Memahami sesuatu berarti membuat koneksi kognitif . Koneksi yang dimaksud adalah situasi konkret, gambar, simbol, dan bahasa matematis. Memahami sesuatu berarti juga membuat koneksi antara pengalaman atau informasi yang baru saja diterimanya dengan pemahaman atau pengetahuan yang telah ada sebelumnya. Hal ini sejalan dengan pendapat Nickerson dalam Barmby, et. al. (2007:41) yang menyebutkan bahwa pemahaman dalam kehidupan sehari-hari dapat ditingkatkan dengan kemampuan untuk membangun jembatan antara satu konsep dengan konsep lainnya. Semakin banyak pengetahuan seseorang, semakin baik orang tersebut dalam memahaminya. Semakin kaya konteks konseptual yang dapat dikaitkan seseorang pada sebuah fakta baru, maka semakin layak orang tersebut dikatakan mengerti akan fakta tersebut.

Alfeld (2004) mengatakan bahwa seseorang dikatakan memahami suatu konsep matematika jika dapat melakukan hal-hal berikut ini:

a. Menjelaskan konsep dan fakta matematika dengan cara yang lebih sederhana.

b. Membuat koneksi logis dengan mudah antara fakta dan konsep yang berbeda.

c. Mengenali koneksi ketika dihadapkan pada sesuatu yang baru (di dalam atau di luar 
matematika) yang berkaitan dengan konsep matematis yang dipahami.

d. Mengidentifikasi prinsip-prinsip suatu konsep matematis yang dapat membuat semuanya bekerja dengan baik.

Pemahaman tidak dapat ditransfer dari siapapun. Setiap orang memahami apa yang dihadapi atau dialaminya dengan cara yang unik. Kegiatan yang sama dan perlakuan yang sama di dalam kelas tidak menjamin akan membentuk kemampuan yang sama pada setiap siswa. Mereka menyerap pelajaran sesuai dengan pengetahuan awal yang mereka miliki dan mengoneksikannya dengan pengalaman yang baru mereka terima di sekolah. Guru dalam kelas bertugas untuk memfasilitasi siswa dalam rangka mencapai pemahaman yang seharusnya ditangkap siswa selama pembelajaran.

Pemahaman tidak dapat diamati secara langsung oleh guru karena pemahaman adalah suatu sikap pandang internal yang harus dicapai secara individu oleh masing-masing siswa (Cockcroft, 1986:232). Dengan kata lain guru tidak bisa benar-benar mengukur sejauh apa pemahaman siswa yang sesungguhnya. Kita hanya perlu mendapatkan penjelasan yang lebih baik tentang pemahaman ini (Portenous, 2008). Akan tetapi, pengukuran ini sangat penting untuk menilai sejauh apa pemahaman yang dimiliki seorang siswa dan sebagai feedback sejauh mana keberhasilan pembelajaran yang dilakukan guru. Perlu adanya suatu batasan atau standar yang dibuat untuk mengetahui sejauh mana pemahaman seorang siswa. Michener (1978:22) mengatakan bahwa pemahaman matematika adalah suatu proses yang dapat dipahami dan mencapai taraf tertentu dari bahan yang sudah diajarkan. Hal ini berarti siswa dianggap paham jika telah menyerap suatu konsep matematis tertentu yang telah dibatasi dan ditetapkan dalam suatu pembelajaran matematika.

Memang tidak mungkin seorang siswa dapat memahami satu materi tertentu secara tuntas, namun pemahaman yang dimaksud dalam tulisan ini adalah pemahaman matematis pada level tertentu pembelajaran matematika yang telah dipertimbangkan dan disusun sesuai dengan karakteristik dan tahap perkembangan siswa. Hal di atas sejalan dengan pendapat Barmby, et. al. (2007:44) bahwa seseorang tidak akan pernah mendapatkan pemahaman yang komplet, karena pemahaman tersebut dapat terus dikembangkan dengan membuat lebih banyak kaitan (link) terhadap apa yang telah dipahami sebelumnya. Pemahaman seseorang akan suatu konsep adalah sesuatu yang abstrak dan bersifat internal, sehingga sulit untuk mengukur dengan tepat bagaimana pemahaman sebenarnya dari seseorang. Namun demikian, Hiebert dan Carpenter (1992) dalam Barmby, et. al. (2007:44) menawarkan metode untuk mengukur (menilai) pemahaman seseorang dengan menganalisis:

a. Students' errors (kesalahan yang dilakukan siswa).

b. Koneksi yang dibuat antara simbol dan prosedur simbolis dan representasi yang bersesuaian.

c. Koneksi yang dibuat antara prosedur simbolis dan situasi pemecahan masalah informal (sehari-hari).

d. Koneksi yang dibuat antara sistem-sistem simbol yang berbeda.

Pemahaman siswa dapat diukur dengan melihat seberapa banyak kesalahan yang dilakukan siswa. Memang siswa sering memberikan jawaban yang benar walaupun mereka tidak memahami apa yang mereka kerjakan. Barmby, et. al. (2007:45) mengatakan bahwa: "The fact that a student gets a calculation correct tells us little about the extent of their understanding. However, when a student makes a mistake in a calculation, then this might indicate the limitations of their understanding, even if that understanding is only instrumental". Apabila kesalahan yang dilakukan siswa sedikit bukan berarti menunjukkan bahwa mereka memahami apa yang dikerjakan. Namun, jika kesalahan yang mereka lakukan begitu banyak, ini mengindikasikan bahwa pemahaman mereka masih rendah.

Berdasarkan berbagai pendapat di atas, dapat disimpulkan bahwa pemahaman matematika merupakan suatu pernyataan mental seseorang berdasarkan pengalaman dan pengetahuan tentang konsep matematis yang diperoleh sebelumnya dan kemampuan membuat koneksi berbagai konsep tersebut untuk memahami situasi atau fakta baru, menyelesaikan permasalahan, atau memperkaya pemahaman sebelumnya. Pemahaman konsep matematis ini terintegrasi dan tersusun dalam pikiran setiap siswa. Siswa mengetahui apa yang harus dilakukan dan mengapa melakukan hal tersebut dengan mengakses kembali konsep matematis tersebut dan merekonstruksinya kembali jika mereka lupa pada saat dihadapkan dengan permasalahan.

Berdasarkan pemahaman dari uraian di atas, penelitian ini memfokuskan pengamatan pemahaman konsep matematis siswa yang mencakup kemampuan untuk menyerap atau memahami ide atau konsep matematis tentang sifat-sifat perkalian dan kemampuan mengaplikasikan konsep secara benar dan tepat 
pada pemecahan masalah, yaitu memahami prosedur menghitung perkalian bilangan cacah.

\section{METODE PENELITIAN}

Penelitian ini menggunakan rancangan Penelitian Tindakan Kelas (PTK). Penelitian dilaksanakan pada siswa kelas II di SDN Gadang 2 Kota Malang. Subjek penelitian dan subjek wawancara sebanyak 5 siswa yang terdiri dari 1 siswa berkemampuan tinggi, 3 siswa berkemampuan sedang, dan 1 siswa berkemampuan rendah. Pemilihan subjek wawancara berdasarkan hasil tes awal dan pertimbangan bahwa siswa-siswa tersebut mudah diajak komunikasi.

Pengumpulan data dalam penelitian melalui tes, pengamatan, wawancara, dan catatan lapangan. Sedangkan data yang dianalisis dalam penelitian ini adalah: 1) data tentang tes hasil belajar, dan 2) data tentang aktivitas peneliti dan siswa selama proses pembelajaran di kelas.

\section{PEMBAHASAN}

\section{Pembelajaran Perkalian dan Sifat-sifat Perkalian Bilangan Cacah}

Sebelum mengenalkan konsep perkalian dan sifat-sifat perkalian bilangan cacah, peneliti terlebih dahulu menyampaikan tujuan pembelajaran. Penyampaian tujuan pembelajaran ini dapat memberikan motivasi belajar pada siswa dan menjadikan siswa lebih fokus pada satu tujuan yang akan dicapai. Pada saat pelaksanaan penelitian ini, siswa nampak sangat antusias memperhatikan penjelasan tujuan pembelajaran yang disampaikan oleh peneliti. Selanjutnya, untuk lebih meningkatkan motivasi siswa, peneliti juga menyampaikan pentingnya konsep perkalian dalam kehidupan sehari-hari dengan memberikan contoh cara menentukan banyak apel dalam keranjang dan menentukan banyak ubin dalam kardus. Hal ini mendukung pendapat Dahar (1988:174) yang mengatakan bahwa penyampaian tujuan pembelajaran dapat memotivasi siswa dan memusatkan perhatian siswa terhadap aspek yang relevan dalam pembelajaran.

Pembelajaran konsep perkalian dan sifatsifat perkalian bilangan cacah dilakukan dengan menggunakan LKS. Penggunaan LKS terbukti sangat membantu arah kerja siswa. Langkahlangkah yang ditentukan dalam LKS merupakan suatu bentuk bantuan bagi siswa. Hal-hal yang perlu dilakukan siswa sehubungan dengan pemanfaatan alat peraga juga dijelaskan dalam
LKS. Meskipun demikian, LKS tidak menuntun siswa secara mutlak. LKS hanya menguraikan langkah-langkah secara garis besar. Siswa masih diberikan kebebasan untuk mengungkapkan ide dan kreativitasnya. Dengan demikian, siswa membentuk pengetahuan mereka sendiri bersama dengan kelompoknya secara aktif dengan bantuan LKS. Hal ini mendukung pendapat Machmud (2001:7) yang mengatakan bahwa LKS dapat memberikan kesempatan kepada siswa untuk bekerja secara mandiri dan bekerjasama, serta memberikan kesempatan kepada siswa untuk melakukan kegiatan penemuan.

Selain menggunakan LKS, dalam pembelajaran konsep perkalian dan sifat-sifat perkalian bilangan cacah juga digunakan alat peraga berupa: 1) tali rafia yang dibentuk persegi panjang dengan ukuran $90 \mathrm{~cm}$ x $120 \mathrm{~cm}$ dan pada masing-masing siku-siku diberi tali berbentuk lubang, dan 2) styrofoam persegi berukuran $3 \mathrm{~cm}$ x $3 \mathrm{~cm}$ yang diberi warna merah, biru, kuning, dan hijau. Penggunaan alat peraga terbukti membantu siswa menemukan dan memahami konsep perkalian dan sifat-sifat perkalian bilangan cacah. Untuk konsep perkalian bilangan cacah, dari 6 kelompok yang ada ternyata semua kelompok dapat menyelesaikan LKS dan menyimpulkan bahwa perkalian bilangan cacah adalah penjumlahan secara berulang. Untuk sifat komutatif, dari 6 kelompok yang ada ternyata semua kelompok dapat menyelesaikan LKS, namun ada yang masih terbalik menyimpulkan. Untuk sifat distributif, dari 6 kelompok yang ada ternyata ada 3 kelompok dapat menyelesaikan LKS dengan benar dan ada 3 kelompok yang belum dapat menyelesaikan LKS dengan benar. Kemudian pada sifat asosiatif, dari 6 kelompok yang ada ternyata ada 5 kelompok dapat menyelesaikan LKS dengan benar dan ada 1 kelompok yang belum dapat menyelesaikan LKS dengan benar. Namun secara garis besar, penggunaan alat peraga dalam penelitian ini terbukti sangat membantu siswa untuk menemukan dan memahami konsep perkalian dan sifat-sifat perkalian bilangan cacah. Proses memanipulasi alat peraga yang dilakukan oleh siswa bersama kelompoknya dapat menumbuhkan pemahaman siswa secara lebih baik. Pembelajaran dengan menggunakan alat peraga ini menjadikan pengetahuan yang diperoleh siswa akan melekat kuat dalam pikirannya. Hal ini mendukung pendapat Weaver dan Suydam (dalam As'ari, 2000:5) yang mengatakan bahwa penggunaan alat peraga merupakan bagian integral dari upaya pembentukan pemahaman dalam pengajaran matematika. 
Pembelajaran konsep perkalian dan sifatsifat perkalian bilangan cacah dalam penelitian ini dilakukan dengan membentuk siswa menjadi 6 kelompok yang terdiri dari 5 siswa. Pemilihan kelompok sebanyak 5 siswa didasarkan pada alasan, jika satu kelompok hanya terdiri dari 2 anggota, maka interaksi antar anggota kelompok akan sangat terbatas dan kelompok menjadi terhenti jika salah satu anggotanya absen. Sebaliknya, jika ukuran kelompok terlalu besar maka akan sulit bagi kelompok itu berfungsi secara efektif. Dalam kelompok yang mempunyai anggota sangat besar, sukar bagi setiap siswa untuk mengutarakan pendapat dan dalam melakukan kerja sama. Hal ini didukung pendapat Artzt dan Newman (1990:449) yang mengatakan bahwa jika kelompok terlalu kecil akan mengakibatkan interaksi yang terbatas dan jika terlalu besar akan mengakibatkan kesulitan dalam melakukan koordinasi dan mencapai kesepakatan.

Kelompok yang terdiri dari 5 siswa ini bersifat heterogen dari segi kemampuan. Pembentukan kelompok secara heterogen dari segi kemampuan didasarkan pada pertimbangan bahwa jika semua anggota kelompok berkemampuan tinggi atau sedang, maka dikhawatirkan terjadi kompetisi dalam kelompok tersebut. Sebaliknya, jika semua anggota kelompok berkemampuan rendah, maka aktivitas kelompok diperkirakan menjadi terhenti. Dengan kelompok heterogen ini siswa berbagi tugas, yakni ada siswa yang bertugas sebagai ketua, pelapor, dan anggota. Pembagian tugas ini ternyata membuat kerja kelompok menjadi efisien.

Kelompok belajar yang terbentuk dalam penelitian ini memberikan banyak keuntungan bagi siswa. Dengan sesama anggota yang lain, siswa saling berdiskusi untuk menyelesaikan pekerjaannya. Masing-masing anggota kelompok saling memberikan bantuan dan masukan dalam meningkatkan pemahamannya tentang suatu konsep. Anggota kelompok yang kurang mampu bertanya kepada anggota kelompok yang lebih mampu mengenai hal-hal yang belum dipahami. Sedangkan siswa yang lebih mampu telah bertambah pemahamannya melalui proses menjelaskan kepada anggota yang kurang mampu. Hal ini mendukung pendapat Eggen dan Kauchak (1996:282) yang mengatakan bahwa dalam kerja kelompok siswa akan saling belajar melalui proses saling menerima dan memberi yang terjadi dalam kelompok.

Hasil kerja kelompok selanjutnya dipresentasikan di depan kelas. Untuk setiap materi dipresentasikan oleh satu kelompok secara bergiliran. Materi perkalian bilangan cacah dipresentasikan oleh kelompok V, materi sifat komutatif dipresentasikan oleh kelompok III, materi sifat distributif dipresentasikan oleh kelompok I, dan materi sifat asosiatif dipresentasikan oleh kelompok IV. Setelah kegiatan presentasi, siswa yang tidak bertugas presentasi memberikan applause kepada siswa yang presentasi. Hal ini membuat kelompok pelapor atau yang presentasi menjadi senang. Penghargaan ini ternyata dapat memotivasi siswa dalam belajar. Hal ini mendukung pendapat Hudojo (1988:279-280) yang mengatakan bahwa penghargaan sangat diperlukan untuk meningkatkan sikap, rasa puas, dan bangga siswa terhadap matematika.

Selanjutnya peneliti mengadakan evaluasi melalui tanya jawab lisan untuk mengecek kembali pemahaman siswa. Peneliti perlu memastikan bahwa semua siswa dapat memahami materi yang baru dipelajari. Sebagai penutup, atas arahan dan bimbingan peneliti siswa menuliskan hasil diskusinya sebagai simpulan akhir pembelajaran. Hal ini didukung pendapat Degeng (1997:28) bahwa membuat rangkuman atau kesimpulan dari apa yang telah dipelajari perlu dilakukan untuk mempertahankan retensi.

\section{Hasil Belajar Siswa tentang Perkalian dan Sifat-sifat Perkalian Bilangan Cacah}

Pembelajaran dengan menggunakan tali rafia dan styrofoam persegi dalam penelitian ini bertujuan untuk meningkatkan pemahaman siswa pada konsep perkalian dan sifat-sifat perkalian bilangan cacah. Setelah dilakukan tindakan, baik tindakan I maupun tindakan II, pemahaman siswa tentang konsep perkalian dan sifat-sifat perkalian bilangan cacah meningkat. Untuk tindakan I, yaitu tentang perkalian bilangan cacah, siswa yang salah menjawab soal hanya $17.24 \%$ dari yang semula $70 \%$. Untuk tindakan II, yaitu tentang sifat-sifat perkalian bilangan cacah, siswa yang salah menjawab soal hanya $20 \%$ dari yang semula $\geq 69 \%$. Sedangkan dari aspek proses, tindakan I menurut pengamat I berada pada kategori baik dan menurut pengamat II berada pada kategori sangat baik. Untuk tindakan II, baik pengamat I maupun pengamat II menilai bahwa proses pembelajaran berada pada kategori baik.

Pembelajaran dengan menggunakan tali rafia dan styrofoam persegi untuk meningkatkan pemahaman siswa pada konsep perkalian dan sifat-sifat perkalian bilangan cacah sudah dapat disimpulkan berhasil. Akan tetapi ada beberapa temuan penelitian yang perlu diperbaiki untuk lebih menyempurnakan hasil penelitian ini, di antaranya: 


\section{a. Alokasi Waktu}

Berdasarkan hasil pelaksanaan penelitian, peneliti menyimpulkan bahwa penggunaan tali rafia dan styrofoam persegi dalam pembelajaran perkalian dan sifat-sifat perkalian bilangan cacah memerlukan alokasi waktu yang lama. Pada saat pelaksanaan, siswa cenderung ramai, gaduh, dan ribut dalam proses pembelajaran. Akibatnya banyak waktu yang tidak dapat digunakan secara efektif karena banyak terbuang untuk menenangkan siswa yang belum kondusif dan belum siap menerima pelajaran. Kondisi yang demikian disebabkan karena siswa belum pernah belajar menggunakan tali rafia dan styrofoam persegi atau media pembelajaran yang lain.

\section{b. Aktivitas Peneliti dan Siswa}

Berdasarkan pengamatan peneliti, lembar pengamatan, dan catatan lapangan, diperoleh informasi bahwa kondisi kelas kurang kondusif pada saat proses pembelajaran berlangsung. Hal ini karena masih terlihat bahwa: 1) siswa cenderung ramai, ribut, gaduh, dan saling rebutan media pembelajaran yang digunakan oleh peneliti pada saat proses pembelajaran berlangsung, khususnya saat akan memulai diskusi kelompok dan saat diskusi kelompok berlangsung, 2) siswa saling berebut menjadi penulis atau mengisi LKS, 3) siswa yang diskusi kelompoknya sudah selesai cenderung mengganggu teman kelompok lain yang sedang mengerjakan LKS, dan 4) peneliti sering dibantu guru kelas dan pengamat untuk menenangkan siswa yang sedang ramai, ribut, dan saling rebutan media pembelajaran saat proses pembelajaran.

Kondisi kelas yang kurang kondusif tersebut tidak berlangsung lama. Kondisi tersebut hanya terjadi pada saat siswa menerima pembagian media pembelajaran dan pada saat kelompok siswa selesai mengerjakan LKS. Kemudian untuk mengelola kelas yang kurang kondusif ini, peneliti dibantu oleh guru kelas dan pengamat menenangkan siswa dan mengatur kelas agar suasana kelas menjadi kondusif. Tujuannya agar proses pembelajaran dapat berjalan dengan baik dan tujuan pembelajaran dapat tercapai.

\section{c. Kebaruan (Novelty) Media Pembelajaran}

Berdasarkan pengamatan peneliti, lembar pengamatan, dan catatan lapangan, siswa terlihat bosan dengan media styrofoam persegi yang digunakan oleh peneliti. Rasa bosan siswa terlihat pada saat pertemuan ketiga pada tindakan II. Siswa terlihat tidak begitu antusias lagi dengan styrofoam persegi yang dibagikan oleh peneliti. Siswa hanya menunggu pembagian styrofoam persegi tersebut untuk dibuat mainan saja, bukan untuk belajar. Siswa yang bertugas menyusun maupun yang bertugas menulis hanya mengikuti petunjuk yang ada pada LKS. Siswa menganggap bahwa cara menyusun styrofoam persegi sama dengan pertemuan sebelumnya, sehingga mereka tidak perlu mengetahui cara menyusunnya lagi. Siswa tidak menggunakan styrofoam persegi lagi karena siswa sudah mulai bosan dan tidak tertarik lagi belajar menggunakan styrofoam persegi. Hal ini mendukung pendapat Asyhar (2011:84) yang mengatakan bahwa kebaruan media yang dipilih harus menjadi pertimbangan sebab media yang lebih baru biasanya lebih baik dan lebih menarik bagi siswa.

\section{d. Kemampuan Siswa Membuat Kesimpulan}

Variasi kesimpulan pada hasil LKS berhubungan dengan perbedaan penyelesaian langkah kerja yang dilakukan oleh masingmasing kelompok, tingkat ketelitian, pemahaman masing-masing kelompok dalam mengerjakan LKS, dan kemampuan alam mengeneralisasikan pola-pola yang mereka temukan dari langahlangkah kerja pada LKS.

Mengeneralisasikan keteraturan pola-pola atau menarik kesimpulan dari kasus-kasus yang bersifat khusus disebut penalaran induktif. Menurut Bennett dan Nelson (2001:24) penalaran induktif merupakan pembentukan kesimpulan berdasarkan pada pola-pola, hasil pengamatan, contoh-contoh maupun percobaanpercobaan. Seorang siswa dapat membuat kesimpulan dimulai dengan mempertimbangkan suatu hal khusus, mengorganisasikan hal khusus tersebut, dan mencari suatu pola yang kemudian dapat menuntun siswa membuat kesimpulan. Sesuai dengan pendapat tersebut dan analisis hasil LKS, dapat dikatakan bahwa sebagian siswa masih lemah dalam bernalar secara induktif karena mereka masih belum dapat melihat keteraturan pola yang terdapat pada langkahlangkah kerja yang dilakukannya dan menggeneralisasikan keteraturan pola tersebut. Hal ini mendukung pendapat Piaget (Orton, 2004:52) bahwa anak usia 7 - 11 tahun perkembangan kognitifnya termasuk dalam tahap operasional konkret sehingga masih belum mampu membuat kesimpulan secara umum.

Ada beberapa kesimpulan menarik dari hasil kerja siswa tentang perkalian dan sifat-sifat perkalian bilangan cacah. Pertama, tentang perkalian bilangan cacah. Kelompok IV dan VI terlihat masih ragu-ragu dalam membuat kesimpulan perkalian bilangan cacah sebagai penjumlahan berulang. Terbukti pada saat menulis $3 \times 4=4+4+4=12$ masih ragu-ragu. 
Pada LKS kelompok IV dan VI terlihat bekas tulisan 3 pada posisi $4+4+4$. Menurut analisis peneliti, kesimpulan yang diperoleh oleh kelompok IV sudah benar. Dimungkinkan pada awalnya terjadi diskusi kelompok yang berbeda pendapat, kemudian diperoleh kesimpulan yang menurut kelompok benar.

Kedua, tentang sifat komutatif perkalian bilangan cacah. Dari 6 kelompok yang ada, hanya kelompok IV yang cara memperoleh kesimpulannya berbeda. Kelompok IV memperoleh kesimpulan dengan cara membandingkan hasil perkalian $3 \times 4$ dan $4 \times 3$, kemudian menyatakan bahwa $4 \times 3=3 \times 4$. Selanjutnya kelompok IV membuat kesimpulan secara umum bahwa $a \times b=b \quad x \quad a$. Menurut analisis peneliti, kesimpulan yang diperoleh oleh kelompok IV sudah benar. Dimungkinkan pada saat menyatakan $3 \times \quad 4$ sama dengan $4 x \quad 3$ melihatnya dari posisi $4 \times 3$.

Ketiga, tentang sifat distributif perkalian bilangan cacah. Ada 4 macam kesimpulan yang diperoleh oleh siswa, yaitu: 1) kelompok I memperoleh kesimpulan $a x(b+c)=(a x b)+(a$ $x \quad$ ) , 2) kelompok II memperoleh kesimpulan $a x$ $\left.(b+c)=\left(\begin{array}{lll}c & x a\end{array}\right)+\left(\begin{array}{lll}b & x & a\end{array}\right), 3\right)$ kelompok III memperoleh kesimpulan $a x(b+c)=(c x b)+(a x$ $d)$, dan 4) kelompok $V$ memperoleh kesimpulan $a$ $x(b+c)=\left(\begin{array}{lll}a & x & c\end{array}\right)+\left(\begin{array}{lll}b & x & a\end{array}\right)$. Setelah dilakukan analisis terhadap hasil kerja siswa, kelompok I memperoleh kesimpulan yang benar sedangkan kelompok II, III, dan V memperoleh kesimpulan yang salah karena tidak mengikuti pola dari langkah-langkah sebelumnya. Pada saat menyatakan $2 \times(3+4)=(2 \times 3)+(2 \times 4)=14$ masih benar. Akan tetapi salah pada saat menyimpulkan secara umum karena siswa tidak memahami pola perkalian bilangan cacah pada langkah sebelumnya.

Keempat, tentang sifat asosiatif perkalian bilangan cacah. Ada 2 macam kesimpulan yang diperoleh oleh siswa, yaitu: 1) kelompok I

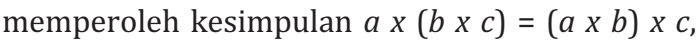
dan 2) kelompok III memperoleh kesimpulan $a x$ $\left(\begin{array}{lll}b & x & c\end{array}\right)=\left(\begin{array}{lll}c & x & b\end{array}\right) \times a$. Menurut analisis peneliti, untuk kelompok I memperoleh kesimpulan yang benar. Sedangkan untuk kelompok III memperoleh kesimpulan yang salah. Dimungkinkan kelompok III menganggap bahwa ini tukar tempat seperti sifat komutatif sehingga semua bilangan $a, b$, dan $c$ berpindah tempat. Kelompok III tidak teliti dan tidak melihat pola perkalian bilangan cacah pada langkah sebelumnya.

\section{Respon Siswa terhadap Pembelajaran Perkalian dan Sifat-sifat Perkalian Bilangan Cacah}

Respon siswa terhadap pembelajaran tentang perkalian dan sifat-sifat perkalian bilangan cacah menggunakan tali rafia dan styrofoam persegi dalam penelitian ini adalah positif. Hal ini terlihat dari hasil wawancara terhadap subjek wawancara yang menyatakan senang, bersemangat, dan dapat meningkatkan pemahaman terhadap konsep perkalian dan sifatsifat perkalian bilangan cacah menggunakan tali rafia dan styrofoam persegi. Begitu pula pada catatan lapangan oleh pengamat I (guru kelas) dan pengamat II yang menyimpulkan bahwa pembelajaran tentang konsep perkalian dan sifatsifat perkalian bilangan cacah menggunakan tali rafia dan styrofoam persegi dapat membuat siswa aktif dalam diskusi dan menyampaikan ideidenya.

Kesenangan siswa juga terlihat ketika sudah berhasil menyusun dan memanipulasi benda kongkret. Mereka terlihat seperti sedang bermain tetapi serius dalam bekerja, misalnya dalam kegiatan perhitungan luasan ubin, menyusun styrofoam persegi atau memanipulasi styrofoam persegi menjadi warna yang lain. Hal ini mendukung pendapat Hudojo (1988:7) bahwa pembelajaran akan lebih menarik dengan penggunaan media.

\section{PENUTUP}

\section{Kesimpulan}

Berdasarkan temuan penelitian dan pembahasan, dapat disimpulkan bahwa: 1) Pembelajaran dengan menggunakan tali rafia dan styrofoam persegi ternyata dapat meningkatkan pemahaman konsep perkalian dan sifat-sifat perkalian bilangan cacah. Pembelajaran ini terdiri dari tiga tahap, yaitu: tahap awal, tahap inti, dan tahap akhir. Pada tahap awal, kegiatan yang dilakukan adalah menyampaikan tujuan pembelajaran, pemberian motivasi tentang pentingnya perkalian bilangan cacah, memeriksa pengetahuan prasyarat, dan membagikan alat peraga dan LKS. Pada tahap inti, kegiatan yang dilakukan adalah proses penemuan konsep perkalian dan sifat-sifat perkalian bilangan cacah. Proses penemuan konsep perkalian dan sifat-sifat perkalian bilangan cacah dibantu penggunaan alat peraga dan LKS. Kemudian diakhiri dengan presentasi hasil diskusi kelompok. Selanjutnya tahap akhir. Kegiatan pada tahap akhir adalah menyimpulkan hasil pembelajaran dan melakukan evaluasi secara lisan melalui tanya jawab, dan 2) Respon siswa terhadap 
pembelajaran menggunakan tali rafia dan styrofoam persegi pada konsep perkalian dan sifat-sifat perkalian bilangan cacah dalam penelitian ini adalah positif.

\section{Saran}

Berdasarkan simpulan di atas, maka saran yang dapat disampaikan adalah: 1) Bagi guru yang ingin menerapkan pembelajaran menggunakan alat peraga, hendaknya: a) mempersiapkan siswa terlebih dahulu agar siap untuk belajar dan membuat pengaturan waktu yang akurat dan efektif, dan b) melakukan pendekatan individu kepada siswa yang ramai, gaduh, berebut alat peraga, dan mengganggu jalannya proses pembelajaran sehingga pelaksanaan pembelajaran dapat berjalan dengan baik, 2) Bagi guru yang ingin menerapkan pembelajaran menggunakan alat peraga untuk pembelajaran materi perkalian dan sifat-sifat perkalian bilangan cacah, hendaknya membuat alat peraga yang bervariasi agar tidak menimbulkan rasa bosan bagi siswa, 3) Bagi guru yang ingin menerapkan pembelajaran dengan menggunakan alat peraga, khususnya untuk pembelajaran materi sifat-sifat perkalian bilangan cacah, hendaknya guru menyusun LKS yang berisi langkah-langkah kerja siswa yang mengarah kepada kesimpulan tentang perkalian dan sifat-sifat perkalian bilangan cacah, dan 4) Bagi peneliti lain yang berminat mengadakan penelitian serupa hendaknya melakukan pada sekolah yang lain sehingga akan diperoleh gambaran lebih lanjut mengenai efektifitas pembelajaran dengan menggunakan tali rafia dan styrofoam persegi pada materi perkalian dan sifat-sifat perkalian bilangan cacah. Selain dilakukan pada sekolah lain, hendaknya tujuan penelitiannya diarahkan pada bagaimana siswa menemukan konsep matematika sendiri.

\section{REFERENSI}

[1] Alfeld, P. 2004. Understanding Mathematics, (Online), (http://www.math.utah. edu/ pa/ math.html), diakses 27 Januari 2012.

[2] Arsyad, A. 2009. Media Pembelajaran. Jakarta: Rajawali Pers.

[3] Artzt, A. F. \& Newman, C. M. 1990. Cooperative Learning. Mathematics Teacher. 83 (6):448-452.

[4] As'ari, A. R. 2000. Mengapa Perlu Penelitian Tindakan. Makalah disampaikan dalam penelitian Action Research Tingkat Nasional bagi para instruktur inti, Cipete, Jakarta.
[5] Asyhar, R. 2011. Kreatif Mengembangkan Media Pembelajaran. Jakarta: Gaung Persada Press.

[6] Barmby, P., Harries, T., Higgins, S., \& Suggate, J. 2007. How Can We Assess Mathematical Understanding? Proceedings of the 31st Conference of the International Group for the Psychology of Mathematics Education, Vol. 2, pp. 41-48. Seoul: PME

[7] Bennett, A. B. \& Nelson, L. T. 2001 . Mathematics For Elementary Teachers (A Conceptual approach) Fifth Edition. USA: McGraw-Hill Companies.

[8] Cockcroft, W. H. 1986. Mathematics Counts. London: Her Majesty's Stationery Office. Dari the History of Education in England, (Online),

(http://www.educationengland.org.uk/docu ments/cockcroft/cockcroft00.html), diakses 27 Januari 2012.

[9] Dahar, R.W. 1988. Teori-teori Belajar. Jakarta: Dedikbud P2LPTK.

[10] Daryanto. 2011. Media Pembelajaran. Bandung: PT. Satu Nusa.

[11] Degeng, I. N. 1997. Strategi Pembelajaran Mengorganisasikan Isi dengan Elaborasi. Malang: IKIP Malang.

[12] Depdiknas. 2006. Peraturan Menteri Pendidikan Nasional Republik Indonesia Nomor 22 Tahun 2006 Tentang Standar Isi Untuk Satuan Pendidikan Dasar dan Menengah. Jakarta: Departemen Pendidikan Nasional.

[13] ............ 2006. Panduan Penyusunan Kurikulum Tingkat Satuan Pendidikan Jenjang Pendidikan Dasar dan Menengah. Jakarta: Badan Standar Nasional Pendidikan.

[14] Djamarah, S. B. \& Zain, A. 2010. Strategi Belajar Mengajar. Jakarta: Rineka Cipta.

[15] Eggen, P. D \& Kauchak, P. P. 1996. Strategies for Teacher: Teaching Content and Thinking Skill. Boston: Alyn \& Bacon.

[16] Heinich, R., Molenda, M., Russel, J. D., \& Smaldino, S. E. 2002. Instructional Media and Technologies for Learning. Upper Saddle River, New Jersey, Columbus, Ohio: Merrill Prentice Hall.

[17] Hudojo, H. 1988. Mengajar Belajar Matematika. Jakarta: Depdikbud.

[18] Karso. 1998. Pendidikan Matematika 1. Jakarta: Departemen Pendidikan dan Kebudayaan. 
[19] Machmud, T. 2001. Implementasi PAM untuk Meningkatkan Kemampuan Siswa dalam Menyelesaikan Soal Program Linier. Tesis tidak diterbitkan. Malang: PPs UM.

[20] Marzuki. 2001. Upaya Meningkatkan Pemahaman Konsep Perkalian Bilangan Cacah dengan Manipulasi Material pada Siswa Kelas II Sekolah Dasar. Tesis tidak diterbitkan. Malang: PPs UM

[21] Michener, E. R. 1978. Understanding Understanding Mathematics. Cambridge, Massachusetts: Massachusetts Institute of Technology.

[22] Orton, A. 2004. Learning Mathematics: Issues, Theory and Classroom Practice. Third Edition. London: Continuum.

[23] Porteous, K. 2008. Understanding Mathematics, (Online), (http://people. exeter.ac.uk/PErnest/pome23/Porteous $\% 2$ 0Understanding\%20Mathematics.doc), diakses 27 Januari 2012.

[24] Ruseffendi, E.T. 1988. Pengajaran Matematika Modern dan Masa Kini untuk Guru dan SPG. Seri Ke Lima. Bandung: Tarsito.
[25] Sadiman, A. S., Rahardjo, R., Haryono, A., \& Rahardjito. 2011. Media Pendidikan: Pengertian, Pengembangan, dan Pemanfaatannya. Jakarta: Rajawali Pers.

[26] Setyosari, P. \& Sihkabuden. 2005. Media Pembelajaran. Malang: Elang Mas.

[27] Skemp, R. R., 1976. Relational Understanding and Instrumental Understanding, (Online), (http://math.coe.uga.edu/Olive/EMAT3500f 08/instrumentalrela tional.pdf), diakses 27 Januari 2012.

[28] Smaldino, S. E., Lowther, D. L., \& Russel, J. D. 2008. Teknologi Pembelajaran dan Media untuk Belajar. Terjemahan Arif Rahman. 2011. Jakarta: Kencana Prenada Media Group.

[29] Soedjadi. 2000. Kiat Pendidikan Matematika di Indonesia. Jakarta: Departemen Pendidikan Nasional.

[30] Sudjana, N. 2011. Dasar-dasar Proses Belajar Mengajar. Bandung: Sinar Baru Algensindo.

[31] Sujono. 1988. Pelajaran Matematika untuk Sekolah Menengah. Jakarta: Departemen Pendidikan dan Kebudayaan. 